\title{
A new tetra-primer ARMS-PCR for genotyping bovine kappa-casein polymorphisms
}

\author{
P.A.S. Fonseca ${ }^{1}$, I.C. Rosse ${ }^{1}$, M. DeMiranda ${ }^{1}$, M.A. Machado ${ }^{2}$, \\ R.S. Verneque ${ }^{2}$, M.G.C.D. Peixoto ${ }^{2}$ and M.R.S. Carvalho ${ }^{1}$ \\ ${ }^{1}$ Departamento de Biologia Geral, Universidade Federal de Minas Gerais, \\ Belo Horizonte, MG, Brasil \\ ${ }^{2}$ Embrapa Gado de Leite, Juiz de Fora, MG, Brasil \\ Corresponding author: M.R.S. Carvalho \\ E-mail: ma.raquel.carvalho@gmail.com
}

Genet. Mol. Res. 12 (4): 6521-6526 (2013)

Received April 8, 2013

Accepted September 26, 2013

Published December 11, 2013

DOI http://dx.doi.org/10.4238/2013.December.11.3

\begin{abstract}
Kappa-casein ( $\kappa$-casein) is one of the most abundant milk proteins. Its main function is to avoid the aggregation of casein micelles, keeping them, and therefore calcium phosphate, in pockets in solution. In bovines, a $\kappa$-casein functional polymorphism has been associated with fat, calcium, and protein milk contents and faster curd contraction in cheese production. Quicker curd contraction reduces the loss of milk solids, enhancing cheese yield. This polymorphism induces a double amino acid substitution (Thr136Ile and Ala148Asp). The polymorphism is normally detected by PCR-RFLP, which is a laborious method. An interesting methodological alternative is the tetra-primer amplification refractory mutation system PCR (tetra-primer ARMS-PCR). A tetraprimer ARMS-PCR for the detection of this $\kappa$-casein polymorphism has been described. However, specificity was not achieved, probably due to problems with primer design. We developed a new tetra-primer ARMSPCR for the detection of the $\kappa$-casein polymorphism. This new method was validated in a double-blind test, by comparison with the results obtained for 50 Guzerá bulls formerly genotyped by PCR-RFLP. This new method achieved 100\% sensitivity and specificity. We conclude
\end{abstract}


that this method is a useful, cost-efficient alternative for the detection of functional $\kappa$-casein polymorphisms.

Key words: Casein; $\kappa$-Casein; CSN3; Tetra-primer ARMS-PCR; $\kappa$-Casein polymorphism

\section{INTRODUCTION}

Over the last few decades, many studies have reported an association of polymorphisms in milk proteins and milk production, contents, and processability (Caroli et al., 2009). Most of these polymorphisms are "guilt by association", only, meaning that they are mostly changes in DNA with no obvious consequences at the protein level. However, some functional polymorphisms have been described that induce amino acid substitutions in milk proteins. Among them, a kappa-casein ( $\kappa$-casein) polymorphism is one of the most tested, because it is one of the most abundant milk proteins. Besides, $\kappa$-casein stabilizes milk micelles, preventing them from aggregating and, therefore, helping to keep calcium phosphate in solution (Boland et al., 2001; Dalgleish and Corredig, 2012).

The most studied polymorphism in $\kappa$-casein is a functional, double amino acid substitution leading to Thr136Ile and Ala148Asp amino acid changes. Due to the strong linkage disequilibrium, this system works as a diallelic one, with alleles A (136Thr and 148Ala) and B (136Ile and 148Asp). The $\kappa$-casein allele B has been associated with higher milk protein content (particularly caseins), shorter rennet clotting time and higher curd firmness, which are coagulation properties that reduce the loss of solids in cheese production (Jakob and Puhan, 1995; Horne et al., 1997; Fitzgerald and Hill, 1997; Kürbarsepp et al., 2005). The $\kappa$-casein allele A has been associated with lower milk fat and calcium amount and a lower milk pH (Kürbarsepp et al., 2005). However, allele B is rare in indicine breeds selected for milk production and has not been found in meat selection zebu herds (Kemenes et al., 1999; Azevedo et al., 2008). To date, no report on the effects of this polymorphism on milk coagulation properties in cheese production in indicine breeds have been published.

Traditionally, this polymorphism has been detected by PCR-RFLP, a polymerase chain reaction amplification plus restriction fragment length polymorphism system with the restriction enzyme HinfI. This is a time-consuming, expensive procedure, and some methodological alternatives have already been described. Since the number of individuals to be tested in selection programs is typically high, simple and less labor-intensive methods are desirable. Alternatives would be real-time PCR (qPCR) and the tetra-primer amplification refractory mutation system (tetra-primer ARMS-PCR; Ye et al., 2001). The latter is an allelespecific PCR based on the amplification of both alleles in the same test tube. The method is based on two allele-specific internal primers, one for each allele of the polymorphism, and two external primers. Therefore, in a heterozygous individual, the system produces three PCR fragments, one for each allele and one between the external primers, providing an exquisite intra-tube PCR control. Its sensitivity and specificity depend on a series of conditions (Ye et al., 2001), which are: 1 . the last 3 ' nucleotide in the primers pairs with the polymorphic nucleotide in DNA; 2. one mismatch inserted in nucleotides -4 to -2 in the 3 'end of the primer; 3 . similar annealing temperature for both internal and external primers; and 4. a 10:1 concentration ratio for internal to external primers. 
The first tetra-primer ARMS-PCR for genotyping $\kappa$-casein was described by Rincón and Medrano (2003). However, this system does not adhere to the conditions of the method described above. Particularly, the annealing temperature of the external primers is much lower than those of the internal ones, so that the annealing temperature of the PCR reaction is limited by the external primers. Therefore, the system is no longer an allele-specific PCR, and unspecific allele amplification is visible in spite of the use of a touchdown PCR program (Figure 2a; Rincón and Medrano, 2003). Here, we describe a new tetra-primer ARMS-PCR for genotyping the $\kappa$-casein Thr136Ile/Ala148Asp double polymorphism.

\section{MATERIAL AND METHODS}

\section{Samples}

The new method was validated by testing 50 bulls belonging to a milk selection system, the Brazilian National Program for Improvement of the Guzerá (Programa Nacional de Melhoramento do Guzerá), coordinated by Empresa Brasileira de Pesquisa Agropecuária (EMBRAPA). These animals had already been genotyped for $\kappa$-casein polymorphism by PCR-RFLP with the restriction enzyme HinfI (Azevedo et al., 2008; Peixoto et al., 2012).

\section{Molecular analyses}

Primers were designed with the Primer3 software (Rozen and Skaletsky, 1999), on the basis of the Bos taurus א-casein reference available in GenBank (Gene ID: 355476774). Primers were chosen according to the above criteria with the following additional criteria: annealing temperature estimated for the external primers approximately $10^{\circ} \mathrm{C}$ higher than that of the internal primers, and $\mathrm{GC}$ content under $50 \%$. Besides, different $\mathrm{MgCl}_{2}$ concentration, $\mathrm{Taq}$ DNA polymerase, and PCR program were tested. Primer sequences, annealing temperature, and the mismatches inserted in the primers (nucleotides underlined) are shown in Table 1. In Figure 1, we show a scheme of the tetra-primer ARMS-PCR system described here. Amplicons differ in 80 base pairs to produce an easy scoring in agarose gel electrophoresis.

\begin{tabular}{lcc}
\multicolumn{2}{c}{ Table 1. Primer sequences, annealing temperatures and GC contents $(\mathrm{GC} \%)$} & \\
\hline Sequence $\left(5^{\prime} \rightarrow 3^{\prime}\right)$ & $\mathrm{Tm}\left({ }^{\circ} \mathrm{C}\right)$ & $\mathrm{GC} \%$ \\
\hline CASKI-For: CACTGTAGCTACTCTAGAGGA & 58 & 47.6 \\
CASKI-Rev: CTCTCAATAACTTCTGGAGGAG & 60 & 45.4 \\
CASKO-For: TCATTTATGGCCATTCCACCAAAG & 68 & 41.6 \\
CASKO-Rev: CCATTTCGCCTTCTCTGTAACAGA & 70 & 45.8 \\
\hline
\end{tabular}

Nucleotides underlined on both internal primers (CASKI for and rev) correspond to the mismatches introduced by us.

In our hands, better PCR conditions were a $25-\mu \mathrm{L}$ final volume of $10 \mathrm{mM}$ Tris, $\mathrm{pH}$ 8.4, $50 \mathrm{mM} \mathrm{KCl}, 0.1 \%$ Triton X-100, $1.75 \mathrm{mM} \mathrm{MgCl}, 0.2 \mathrm{mM}$ of each dNTP, 8\% DMSO, 1 U Taq DNA polymerase, $50 \mathrm{ng}$ genomic DNA, and 25 pmol internal primers (CASKI-For and CASKI-Rev) and external primers (CASKO-For and CASKO-Rev) (Table 1). The PCR amplification program consisted of a 5-min initial denaturation step, followed by 30 cycles of $94^{\circ} \mathrm{C}$ for $30 \mathrm{~s}, 60^{\circ} \mathrm{C}$ for $30 \mathrm{~s}$, and $72^{\circ} \mathrm{C}$ for $30 \mathrm{~s}$, and a last extension step at and $72^{\circ} \mathrm{C}$ for $5 \mathrm{~min}$. 
PCR products were electrophoresed on $2 \%$ agarose gels stained with ethidium bromide or $8 \%$ polyacrylamide gels stained with silver nitrate (Sambrook and Russell, 2001).

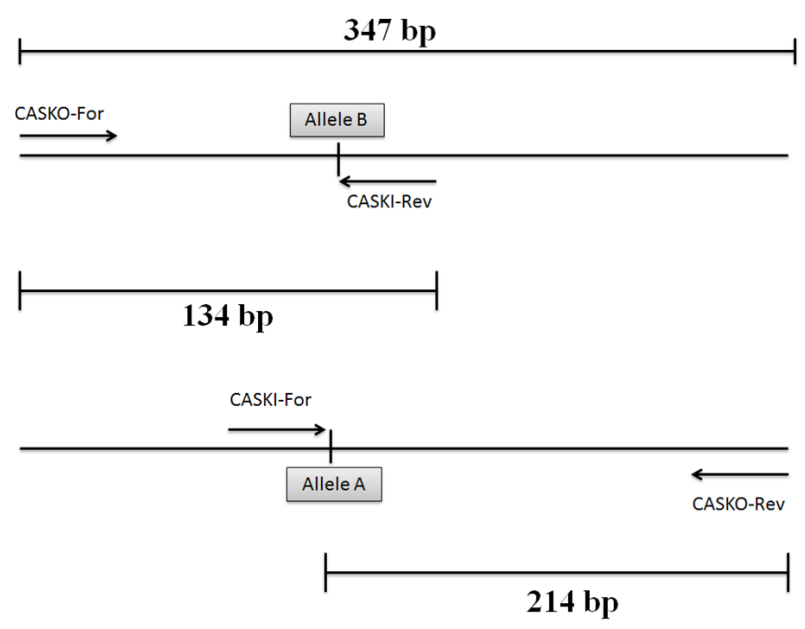

Figure 1. Schematic representation of the tetra-primer ARMS-PCR for the detection of the bovine $\kappa$-casein double polymorphism Thr136Ile/Ala148Asp. A $347 \mathrm{bp}$ amplicon is produced by the external primers. This band works as an intra-tube amplification control. The allele A is detected by the amplification of CASKI-For and CASKO-Rev (214 bp). The allele B is detected by the amplicon of primers CASKI-Rev and CASKO-For (134 bp).

\section{RESULTS AND DISCUSSION}

An example of how the new tetra-primer ARMS-PCR works for the detection of the bovine $\kappa$-casein double polymorphism Thr136Ile/Ala148Asp is shown in Figure 2. The larger band (347 bp) is the product of external primer amplification. Allele A produces a 214-bp band (Figure 2, lanes 2 and 3) and allele B a 134-bp one (Figure 2, lanes 6 and 7). The heterozygote amplification pattern is shown in lanes 4 and 5. Note that no unspecific bands are visible, not even in silver-stained polyacrylamide gels, a method 50 times more sensitive than ethidium bromide-stained agarose gels (Sambrook and Russell, 2001).

To ascertain sensitivity and specificity, the results obtained with tetra-primer ARMSPCR were compared to those from PCR-RFLP genotyping. A 100\% concordance between the results of the two methods was obtained, suggesting both high sensitivity and specificity. Therefore, the changes we introduced in the original criteria of tetra-primer ARMS-PCR design (Ye et al., 2001) led to better results than those obtained by others (Rincón and Medrano, 2003) who tested the effects of lower annealing temperature of the allele-specific primers relative to the external primers. We were able to achieve a truly specific genotyping method only by choosing lower annealing temperatures for the allele-specific primers. Indeed, we have already successfully tested this very same approach in a genotyping test we described a couple of years ago, namely a tetra-primer ARMS-PCR for the detection of DGAT-1 K232A polymorphism (Steinberg et al., 2009). In conclusion, the tetra-primer ARMS-PCR described here offers an easy, cost-efficient, highly sensitive and specific alternative for the detection of the bovine $\kappa$-casein double polymorphism Thr136Ile/Ala148Asp. 


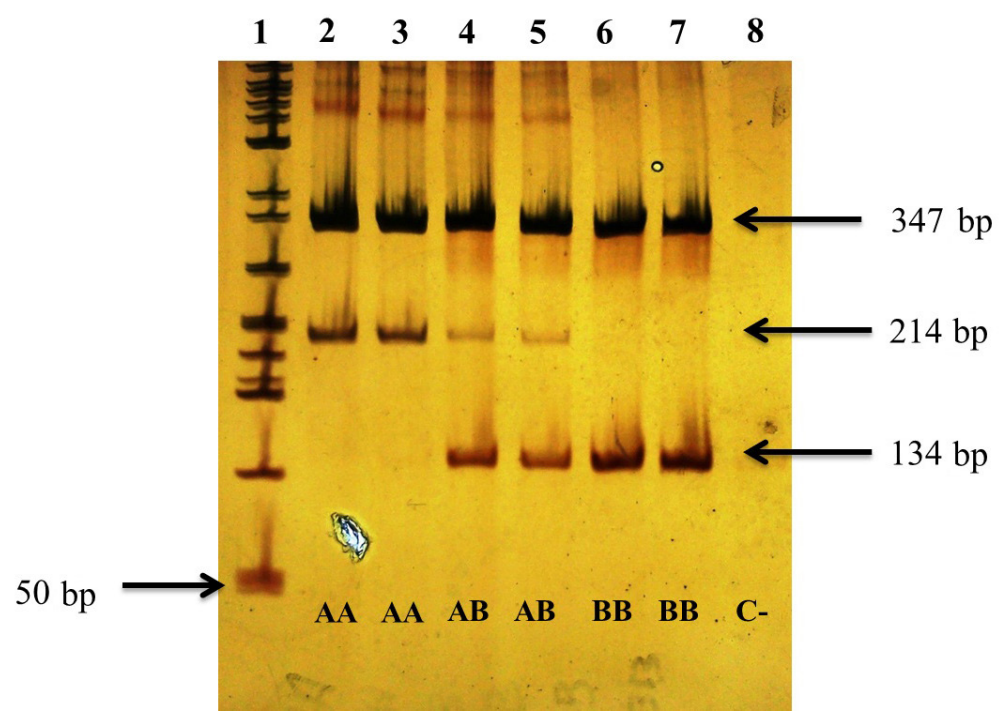

Figure 2. Silver stained polyacrylamide gel (8\%). Lane $1=50$ bp ladder; lanes 2 and $3=$ two homozygotes for the $\kappa$-casein AA genotype; (the $347 \mathrm{bp}$ corresponds to the external control and the $214 \mathrm{bp}$ is the allele specific fragment); lanes 4 and $5=$ two heterozygous individuals ( 347 and 214 bp bands and a 134 fragment, correspond to allele B); lanes 6 and $7=$ two BB homozygotes (347 and $134 \mathrm{bp}$ fragments); lane $8=$ negative PCR control (PCR mix plus water).

\section{ACKNOWLEDGMENTS}

Research supported by Fundação de Amparo à Pesquisa do Estado de Minas Gerais (FAPEMIG), Conselho Nacional de Pesquisa (CNPq), Pró-Reitoria de Pesquisa de Universidade Federal de Minas gerais (PRPq/UFMG), and Coordenação de Aperfeiçoamento de Pessoal de Nível Superior (CAPES). MRSC, PASF, MAM, and RSV have CNPq fellowships. IRC has a CAPES fellowship. We are grateful to Professor Vânia Maldini Pena and Ms. Ariane Figueiredo Menicucci from Colégio Brasileiro de Criadores do Guzerá, for providing biological samples.

\section{REFERENCES}

Azevedo AL, Nascimento CS, Steinberg RS, Carvalho MR, et al. (2008). Genetic polymorphism of the kappa-casein gene in Brazilian cattle. Genet. Mol. Res. 7: 623-630.

Boland M, MacGibbon A and Hill J (2001). Designer milks for the new millennium. Livest. Prod. Sci. 72: 99-109.

Caroli AM, Chessa S and Erhardt GJ (2009). Invited review: milk protein polymorphisms in cattle: effect on animal breeding and human nutrition. J. Dairy Sci. 92: 5335-5352.

Dalgleish DG and Corredig M (2012). The structure of the casein micelle of milk and its changes during processing. Annu. Rev. Food Sci. Technol. 3: 449-467.

Fitzgerald R and Hill J (1997). The Relationship Between Milk Protein Polymorphism and the Manufacture and Functionality of Dairy Product. Milk Protein Polymorphism. Bulletin IDF. IDF, Brussels Belgium, 355- 371.

Horne DS, Banks MJ and Muir DD (1997). Genetic Polymorphism of Bovine $\kappa$-casein: Effects on Renneting and Cheese Yield. In: Milk Protein Polymorphism. International Daily Federation, Brussels, 162-171.

Jakob E and Puhan Z (1995). Implications of Genetic Polymorphism of Milk Proteins on Production and Processing of 
Milk. In: Bulletin of the International Dairy Federation (IDF Seminar March 28-29). Zurich, 2-24.

Kemenes PA, Regitano LCA, Rosa AJM, Packer IU, et al. (1999). $\kappa$-casein, $\beta$-lactoglobulin and growth hormone allele frequencies and genetic distances in Nelore, Gyr, Guzerá, Caracu, Charolais, Canchim, and Santa Gertrudis cattle. Genet. Mol. Biol. 22: 539-541.

Kübarsepp I, Henno M, Viinalass H and Sabre D (2005). Effect of $\kappa$-casein and $\beta$-lactogobulin genotypes on the milk rennet coagulation properties. Agr. Res. 3: 55-64.

Peixoto MGCD, Teodoro RL, Verneque RS, Panetto JCC, et al (2012). Programa Nacional de Melhoramento do Guzerá para Leite: Resultados do Teste de Progênie, do Programa de Melhoramento Genético de Zebuínos da ABCZ e do Núcleo MOET. Embrapa Gado de Leite, Juiz de Fora.

Rincón G and Medrano JF (2003). Single nucleotide polymorphism genotyping of bovine milk protein genes using the tetra-primer ARMS-PCR. J. Anim. Breed. Genet. 120: 333-337.

Rozen S and Skaletsky HJ (2000). Primer3 on the WWW for general users and for biologist programmers. Bioinformatics methods and protocols. Methods Mol. Biol. 132:365-86.

Sambrook J and Russell DW (2001). Molecular Cloning. A Laboratory Manual. Cold Spring Harbor Press, Cold Spring Harbor.

Steinberg RS, Pereira L, Lacorte GA, Peixoto MG, et al. (2009). Technical note: A new and cost-effective method for detection of the bovine acyl-CoA:diacylglycerol acyltransferase $1 \mathrm{~K} 232 \mathrm{~A}$ polymorphism in cattle. J. Dairy Sci. 92: 773-776.

Ye S, Dhillon S, Ke X, Collins AR, et al. (2001). An efficient procedure for genotyping single nucleotide polymorphisms. Nucleic Acids Res. 29: E88. 